\title{
Opportunities for motor stimulation in the home environment of children
}

\author{
Walan Robert da Silva1, Tailine Lisboa', Elisa Pinheiro Ferrari2,6, Kamyla Thais Dias de Freitas', \\ Fernando Luiz Cardoso ${ }^{3}$, Nara Fabiane de Almeida Motta ${ }^{4}$, Claudio Marcelo Tkac ${ }^{5}$
}

Doi: http://dx.doi.org/10.7322/jhgd.127659

\begin{abstract}
Introduction: The environment in which the child is inserted and motor opportunities offered to this is essential for a good motor development.

Objective: To analyze the relationship between the motor stimulation opportunities in the family environment and children's motor development of both sex.

Methods: were evaluated 72 children, 33 boys and 39 girls with age of 38 to 42 months. The evaluation was conducted by Affordances in the Home Environment for Motor Development (AHEMD) and the Test of Gross Motor Development-2 (TGMD-2). Were used the tests Chi-square, Fisher exact test, $t$ test for independent samples, Pearson correlation and multiple linear regression.

Results: In general, the households have low opportunities for motor stimulation, and for households with boys the score is higher. The girls performed better in locomotor skills, while boys had higher scores on object control skills. It found a significant correlation to motricity materials and thick materials motor for boys and variety of stimulation, fine motor materials, motricity materials and motor stimulation for girls. For the boys the motor performance is explained by the available variables of fine and gross motor skills and for the girls by materials of motor stimulation, stimulation variety and materials of fine and gross motor skills.
\end{abstract}

Conclusion: On the presented results we can conclude that the home environment is directly related to the motor development of girls and boys.

Keywords: motor stimulation, home environment motor development.

\section{INTRODUCTION}

Child development is a multifaceted aspect influenced by several factors, including environmental ${ }^{1-3}$. The development of children may occur in different ways, depending on the social environment in which they are inserted $^{4}$. Consequently, the family environment stands out as a factor of child development ${ }^{5}$. In this regard, Bronfenbrenner ${ }^{6}$ states that the family and the school are the main primary child development contexts, and are responsible for much of the development of motor capacity ${ }^{4}$.

Thus, in the early years of a child's development the physical composition of the environment establishes itself as one of the first means of motor experience ${ }^{7}$. In this phase, the discovery of his environment happens in a unique way, since during this period the motor action predominates the cognitive, in this way, the relationship that is established between the child and the context where he is developed is key for his motor development ${ }^{8}$. The interior of the house and its surroundings are configured as the first external environments for experimentation during the early years of life for most children, as they spend most of their time at home. Therefore, the domestic environment proves to be an important factor in children's overall development. In addition, the availability of stimuli such as toys, books and games is an indicator of the overall home quality ${ }^{7}$.

1 Mestrando junto ao programa de pós-graduação em ciências do movimento humano da universidade do estado de Santa Catarina, UDESC/laboratório de gênero, educação, sexualidade e corporeidade, LAGESC, Florianópolis-SC, Brasil.

2 Doutoranda junto ao programa de pós-graduação em ciências do movimento humano da universidade do Estado de Santa Catarina, UDESC/laboratório de gênero, educação, sexualidade e corporeidade, LAGESC, Florianópolis-SC, Brasil.

3 Professor junto ao programa de pós-graduação em ciências do movimento humano e do programa de pós-graduação em educação da universidade do estado de Santa Catarina, UDESC/laboratório de gênero, educação, sexualidade e corporeidade, LAGESC, Florianópolis-SC, Brasil.

4 Graduada em licenciatura em educação física, escola de biociências da Universidade Católica do Paraná, pesquisadora do grupo de pesquisa em comportamento motor, GECOM, Curitiba-PR, Brasil.

5 Professor junto a Pontifícia Universidade Católica do Paraná, Escola de Saúde e Biociências, Curso de Educação Física/Grupo de Pesquisa em Comportamento Motor, GECOM, Curitiba-PR, Brasil.

6 Bolsista Capes.

Corresponding author: Elisa Pinheiro Ferrari. E-mail: elisaferrari_@hotmail.com

Suggested citation: Silva WR, Lisboa T, Ferrari EP, Freitas KTD, Cardoso FL, Motta NFA, et al. Opportunities for motor stimulation in the home environment of children. J Hum Growth Dev. 2017; 7(1): 84-90. Doi: http://dx.doi.org/10.7322/jhgd.127659

Manuscript submitted 2016, accepted for publication Jun 2016. 
Understanding the importance of the environment for individual development, Gibson ${ }^{9}$ proposed the theory of affordances and opportunities offered by the environment for individual action and, consequently, for learning and developing a skill, and thus the notion that home may or may not offer stimuli that are more or less conducive to the child's development ${ }^{10}$. Therefore, in light of the principles of the sequence and continuity of a lifetime motor ${ }^{11}$ development approach, it is assumed that motor development is influenced by the affordances in the home since the beginning of the basic fundamental motor according to the gender. However, there is no consensus in the current literature about the relationship between these variables ${ }^{5,7,12-14}$ and whether the same behaviour differs between the sexes, since most studies do not discriminate the results in relation to sex.

Thus, the present study aimed to analyze the relationship between opportunities for motor stimulation in the family atmosphere and the motor development of children.

\section{METHODS}

\section{Characterization of the study}

The study is characterized as descriptive, crosssectional and associative, and was performed in 2014 with children aged between 38 and 42 months from a municipal school in the city of Campina Grande do Sul, Paraná, Brazil. Submitted and approved by the Research Ethics Committee of the Pontifical Catholic University of Paraná under number 130,202/CAAE: 08806812.0.0000.0020.

\section{Participants}

Parents and representatives of children aged between 38 and 42 months enrolled in a municipal school in the city of Campina Grande do Sul, Paraná, Brazil were invited to participate in the study. The following inclusion criteria were considered: age as stipulated earlier; agreement to participate in the study; provision of informed consent signed by the parents or representatives.

\section{Collection instruments and procedures}

To evaluate opportunities for motor stimulation, the AffordFFances in the Home Environment for Motor Development (AHEMD) questionnaire, developed by Rao, Sami and Gabbard ${ }^{15}$, translated and validated for Brazil by Caçola et al. ${ }^{16}$, was applied to assess the quantity and quality of opportunities for motor stimulation that the family context offers for the development of these children.

The questionnaire is addressed to those responsible for children aged between 38 and 42 months and is composed of five subscales: (1) external environment, (2) interior space, (3) range of stimulation, (4) fine motility and material, and (5) motility thick materials. These subscales are classified hierarchically in four levels and the total score of the questionnaire varies from 5 to 20 points, which is finally ranked on a standardized scale of four categories: "very weak", "weak", "good" and "very good". For some analysis categories they were grouped into "suitable" (good and very good) and "inappropriate" (weak and very weak).
The evaluation of motor development was accomplished through the Test of Gross Motor Development-2 (TGMD-2), developed by Ulrich in 2000 and validated for the Brazilian population by Valentini et al. ${ }^{17}$. The TGMD2 consists of an analysis of six motor tasks (running, jumping on one leg, jumping horizontally, jumping over an obstacle, sliding and sprinting) and six object control tasks (swing, catch, bounce, pitch, roll and kick); the performance of each child in the tasks of that test was filmed for later analysis. Each task had a number of performance criteria for the qualitative analysis of movement; the child received one (1) point if it was answered according to the criteria and no point if he didn't answer. From this the sum of the points obtained in each subtest was obtained, and classified in the test as raw scores. The analysis of the performance criteria was done by two trained evaluators experienced in the evaluation of the test.

Data collection was carried out in the children's own educational institution, where each child was filmed performing the TGMD-2 in the presence of only two people, who had been previously trained and were experienced in its application. All tests were applied by the same instructor, and for each skill tested three attempts were made (one practice and two for further analysis).

After the motor tests, the questionnaire concerning opportunities for motor stimulation, the AHEMD, was sent out for parents or representatives to fill them in.

\section{Statistical analysis}

The results were analysed using the statistical program Statistical Package for Social Sciences (SPSS) ${ }^{\circledR}$ version 20.0. It was initially held a descriptive statistics by means of the values of average, standard deviation, absolute and relative frequencies.

The association between the subscales of the AHEMD and the TGMD-2 was verified through the Chisquare test and Fisher's exact test. To verify the differences between the genders in relation to motor development opportunities a t-test for independent samples was used, and the data showed normal distribution, which was verified through the Kolmogorov-Smirnov test. The

Pearson correlation test was employed to determine the relationship between the AHEMD subscales and the motor development and the association between the variables through the multiple linear regression test. For all the analyses the significance level adopted was 5\%.

\section{RESULTS}

With regard to opportunities for stimulation, $63.5 \%$ of homes with female children were considered to have very weak opportunities. Among homes with male children, the opportunities were a little better, since only $33.3 \%$ were regarded as possessing very weak opportunities (Figure 1).

When checking the ratings of the subscales comprising the assessment tool motor stimulation opportunities between genders, no differences were found ( $p$-value $>0.05$ ) (Table 1). Another important aspect of Table 1 is the higher prevalence of inadequacy of opportunities for 
Figure 1: General classification of motor stimulation opportunities in home environment according to the gender value of $x^{2}=p \leq 0.001$

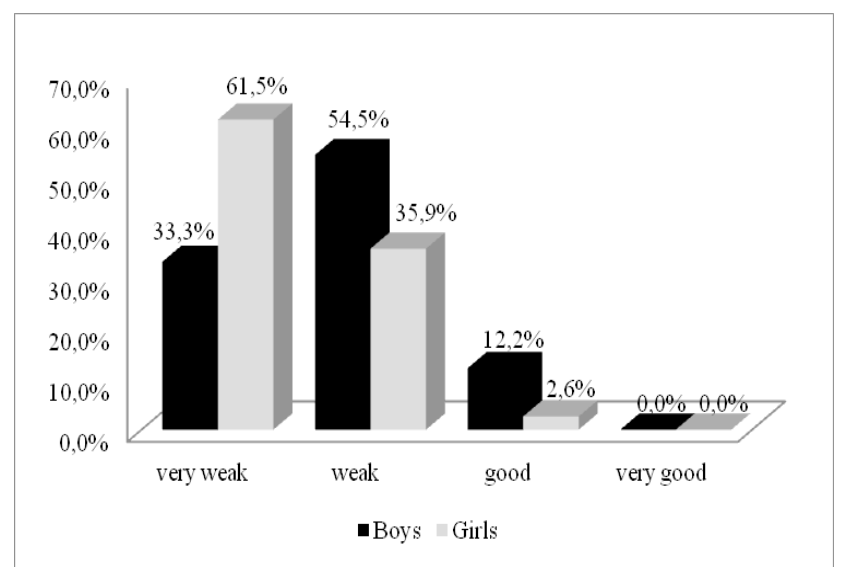

Source: The author

Table 1: Frequency distribution of the subscales and the overall rating of the AHMED instrument according to gender

\begin{tabular}{|c|c|c|c|c|}
\hline & \multicolumn{2}{|c|}{ Adequate } & \multicolumn{2}{|c|}{ Inadequate } \\
\hline & $\begin{array}{c}\text { B Boys } \\
\% \text { (n) }\end{array}$ & $\begin{array}{l}\text { G Girls } \\
\% \text { (n) }\end{array}$ & $\begin{array}{c}\text { B Boys } \\
\% \text { (n) }\end{array}$ & $\begin{array}{c}\text { G Girls } \\
\% \text { (n) }\end{array}$ \\
\hline External environment & $39.4(13)$ & $33.3(13)$ & $60.6(20)$ & $66.7(26)$ \\
\hline Internal environment & $81.8(27)$ & $69.2(27)$ & $118.2(06)$ & $50.8(12)$ \\
\hline Fine motricity materials & $51.5(17)$ & $43.6(17)$ & $48.5(16)$ & $56.4(22)$ \\
\hline Gross motricity materials & $66.7(22)$ & $56.4(22)$ & $33.3(11)$ & $33.6(17)$ \\
\hline Variations of stimulation & $63.6(21)$ & $36.4(12)$ & $66.4(22)$ & $33.6(17)$ \\
\hline General classification & $12.1(04)$ & $26(01)$ & $87.9(29)$ & $97.4(38)$ \\
\hline
\end{tabular}

*Significance level $p<0.05$ of the p-value regarding the Qui-square text and Fiher's Exact Test.

motor stimulation in these households, although the prevalence for homes with children exceeds $50.0 \%$.

Table 2 shows the percentiles of the variables of motor development in the sample studied. The girls achieved better performance in motor skills, while the boys showed higher scores in the object skills. However, these differences between the genders were not considered statistically significant.

Table 2: Media of percentiles of motor development distributed in the subscales: Locomotor and Object control according to the gender

\begin{tabular}{lcccc}
\hline Classification & $\begin{array}{c}\text { Boys } \\
\mathbf{x}(\mathbf{d} \mathbf{p})\end{array}$ & $\begin{array}{c}\text { Girls } \\
\mathbf{x}(\mathbf{d} \mathbf{p})\end{array}$ & T test & p-value \\
\hline Locomotor & $54.6(4.9)$ & $55.9(5.0)$ & -.887 & .386 \\
Object control & $45.4(4.9)$ & $44.0(5.03)$ & -.888 & .385 \\
Total & $58.8(10.9)$ & $53.3(10.3)$ & 1.68 & .100 \\
\hline
\end{tabular}

*Significance level $p<0.05$ of the $p$-value regarding the $t$ test for independent samples.

With regard to motor development, $41.0 \%$ of female children were considered to have higher level of mo- tor development. Between the male children, the performance was slightly better (45.5\%) (Figure 2).

Figure 2: Classification of motor performance level according to gender

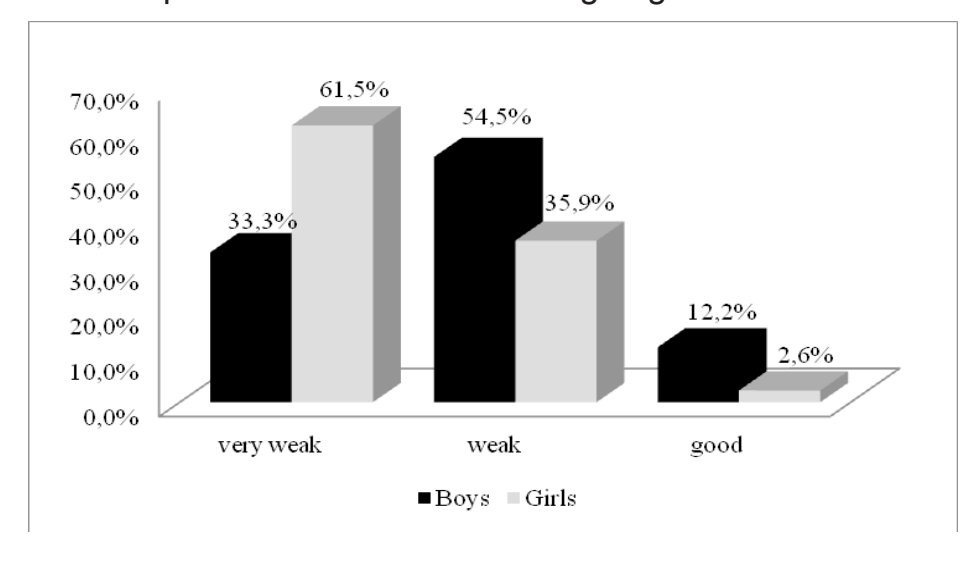


When considering the relationship between motor development and the subscales comprising motor stimulation opportunities in the family context, moderate and strong correlations were observed for male children for the provision of materials for fine motor function $(r=0.773)$ and motility thick materials $(r=0.618)$. For the female children, moderate correlations were observed for the variety of stimulation $(\mathrm{r}=0.540)$, fine motility materials $(r=0.641)$, motility thick materials $(r=0.602)$ and motor stimulation $(\mathrm{r}=0.433)$ (Table 3).

Table 3: Correlation between the opportunities for motor stimulation and scores evaluating the motor development of children

\begin{tabular}{lcc}
\hline Variable & $\begin{array}{c}\text { Male gender } \\
(\mathbf{r})\end{array}$ & $\begin{array}{c}\text { Female gender } \\
(\mathbf{r})\end{array}$ \\
\hline Internal environment & .015 & .109 \\
External environment & .062 & .150 \\
Variations of stimulation & .287 & $.540^{*}$ \\
Fine motricity materials & $.773^{*}$ & $.641^{*}$ \\
Gross motricity materials & $.618^{*}$ & $.602^{*}$ \\
Total motor stimulation & .073 & $.433^{*}$ \\
\hline
\end{tabular}

*p-value $<0.05$ in the Pearson's correlation test.

In the linear regression analysis of the correlation between opportunities for motor stimulation in the family atmosphere and the motor development of children it can be verified that the independent variables that have a relationship with motor development were fine motility materials $(\beta=0.592$; $\mathrm{CI}, 18.6$ to $4.01, \mathrm{p}<0.003)$ and motility thick materials $(\beta=0.203$; CI, 10.9 to $3.32, \mathrm{p}<0.005)$, which explained $54.8 \%$ of the variation in motor development for children. And the variables materials of fine motility ( $\beta=0.380$; $\mathrm{CI}, 15.8$ to $1.62, \mathrm{p}<0.005)$, motility thick materials ( $\beta=0.123$; CI, 10.9 to $6.51, p<0.005)$, variety of stimulation ( $\beta=0.296$; IC, 12.9 to $2.68, \mathrm{p}<0.005$ ) and motor stimulation $(\beta=0.176$; IC, 19.9 to 3.48 , $\mathrm{p}<0.005)$ explained the motor development in $55.8 \%$ of the girls investigated.

\section{DISCUSSION}

In verifying the relationship between opportunities for motor stimulation in familiar surroundings and the motor development of children of both genders, it is observed that the households evaluated presented few opportunities for motor stimulation. In other studies ${ }^{12,18-23}$, there was negative evidence regarding opportunities for motor stimulation in the home environment. The home environment is considered crucial to the development of the child ${ }^{23,24}$. However, it can be seen that this environment doesn't create opportunities or encourage the motor development of the children examined, and other microsystems, such as educational institutions, are responsible for providing such stimulation, so that the motor development of those children will not be compromised ${ }^{23}$.

By stratifying by gender, the homes with male children showed higher motor stimulation scores than girls' homes. In general, the carers, the majority of whom are mothers, set the rules according to the gender of the children, which determines the materials to be used, as well as the typical games ${ }^{25}$ and the organization of home ${ }^{26}$ spaces, situations that can influence stimulating opportunities for boys and girls.

With respect to the degrees or subscales of motor stimulation in children, subscales that examined the exter- nal space were the most inadequate variable, which is in line with the results of other previous studies. In a survey conducted in the homes of children in Ceará, Brazil, it was found that the external environment of most analysed residences did not offer sufficient opportunities for the motor development of the children ${ }^{12}$. So, as in Várzea Alegre, Ceará, Brazil, where few external environment opportunities for children were found ${ }^{13}$.

The typology of households is an important factor in the infant motor development process, since the physical spaces in structured environments provide a range of stimuli $^{22}$. Therefore, these findings justify the need for the development and construction of public leisure areas that offer a minimum footprint for better motor development of children, given that the current available studied homes are not suitable for motor enhancement.

When we look at the classification of evaluation in the TGMD-2, less than half of the children tested, $45.5 \%$ of boys and $41.0 \%$ girls, showed high motor development. These results are in line with other studies that have shown a high prevalence of children with inadequate ${ }^{27,28}$ motor development, thereby suggesting that the low level of motor stimulation opportunities offered to the children investigated seems to influence motor development as a whole.

Another aspect noted is the better performance of children's motor patterns in relation to others. This improved performance of motor skills in the age investigated is explained by the child's own process of motor development, taking into consideration the sequence and continuity principles proposed by Gallahue, Ozmun and Goodway ${ }^{11}$, which claim that rudimentary motor patterns are acquired before more complex actions such as handling objects ${ }^{29}$, thereby justifying the outcome found. With respect to motor performance, the girls were better than the boys, a fact justified by the faster maturational development in girls, which contributes to their better performance in motor skills ${ }^{11}$.

However, in the classification of control of objects the boys showed better results, which may be explained by the fact that they are more prepared to join in the fun and games, thereby showing a greater tendency to acquire motor skills involving handling objects ${ }^{29}$. Consequently, 
the better performance from the boys in the control of objects is associated with the characteristics of the culture in which they are inserted ${ }^{30}$.

When correlating the opportunities in the home environment and motor development, a significant correlation was found for fine and gross motor skills for the boys and a variety of stimulation, and materials of fine and gross motor skills and motor stimulation for the girls. These results were confirmed by the multiple linear regression performed, and are justified, since girls develop earlier than boys and are more patient in performing fine motor activities, which causes the AHEMD to be more compatible with the female gender ${ }^{13}$. In addition, these authors attribute this finding to a greater importance of the variables variety of stimulation and the presence of materials of fine and thick motility, in relation to other subscales that compose the AHEMD.

Regression analysis revealed that the variety of stimulation can be a significant predictor for motor development. This discovery suggests that an adequate amount of stimuli at home can increase the effect of the environment ${ }^{20,31}$. In general, these results show promising evidence to support the prediction that, with a good score of affordance, there is a likelihood of good motor development, thereby making the maintenance of locations where children have opportunities for playing and recreation important $^{12,32}$.

In front of these results, is highlighted the awareness of parents and teachers of the importance of motor opportunities, mainly related to gross motor skills involving fundamental movements, as practical implications of this research.

The limitations of this study include the transverse character used, which does not allow causal inference, as well as the use of non-probability sampling, which does not allow for the extrapolation of data to the entire population of this age group.

However, these findings can assist in the implementation of policies, programmes and actions directed at the child population, by means of practical guidelines designed to minimize the effect of inadequate environments by increasing the quality and quantity of areas and equipment in order to optimize the development of the child and the promotion of health.

The home environment is directly related to the motor development of girls and boys. Girls come from a home environment with a greater variety of stimulation, handling materials of fine and gross motricity, and boys who reside in households handling materials of fine and gross motricity showed better levels of motor development.

\section{REFERENCES}

1. Miranda LP, Resegue R, Figueiras ACM. A criança e o adolescente com problemas do desenvolvimento no ambulatório de pediatria. J Pediatr. 2003;79(supl.1):33-42. DOI: http://dx.doi.org/10.1590/S002175572003000700005

2. Mancini MC, Megale L, Brandão MB, Melo APP, Sampaio RF. Efeito moderador do risco social na relação entre risco biológico e desempenho funcional infantil. Rev Bras Saúde Mater Infant. 2004;4(1):25-34. Doi: http://dx.doi.org/10.1590/S1519-38292004000100003

3. Pilz EML, Schermann LB. Determinantes biológicos e ambientais no desenvolvimento neuropsicomotor em uma amostra de crianças de Canoas/RS. Ciênc Saúde Coletiva. 2007;12 (1):181-90. DOI: http:// dx.doi.org/10.1590/S1413-81232007000100021

4. Venetsanou F, Kambas A. Environmental affecting preschoolers' motor development. Early Child Educ J. 2010;37(4):319-27. DOI: http://dx.doi.org/10.1007/s10643-009-0350-z

5. Saccani R, Valentini NC, Pereira KRG, Müller A, Gabbard C. Associations of biological factors and affordances in the home with infant motor development. Pediatr Int. 2013;55(2): 197. DOI: http://dx.doi. org/10.1111/ped.12042

6. Martins E, Szymanski H. A abordagem ecológica de Urie Bronfenbrenner em estudos com famílias. Estud Pesqui Psicol. 2004;4(1):63-77.

7. Haydari A, Askari P, Nezhad MZ. Relations hip between affordances in the home environmentand motor development in children age 1842 months. J Social Sci. 2009;5(4): 319-28. DOI: http://dx.doi.org/10.3844/ jssp.2009.319.328

8. Payne VG, Isaacs LD. Desenvolvimento motor humano: uma abordagem vitalícia. 6 ed. Rio de Janeiro: Guanabara Koogan; 2007.

9. Gibson EJ. Exploratory behavior in the development of perceiving, acting and the acquiring of know ledge. Rev Psychol. 1988;39:1-42. DOI: http://dx.doi.org/10.1146/annurev.ps.39.020188.000245

10. Heft, H. Affordances of children' senvir on ments: A functional approach to environmental description. Children's Environments Quarterly. 1998;5(3):29-37.

11. Gallahue DL, Ozmun JC, Goodway JD. Compreendendo o desenvolvimento motor. 7 ed. Porto Alegre: Artmed; 2013.

12. Nobre FSS, Costa CLA, Oliveira DL, Cabral DA, Nobre GC, Caçola P. Análise das oportunidades para o desenvolvimento motor (affordances) em ambientes domésticos no Ceará - Brasil. Rev Bras Crescimento Desenvol Hum. 2009;19(1):9-18. DOl: http://dx.doi.org/10.7322/jhgd.19898

13. Nobre FSS, Pontes ALFN, Costa CLA, Cacola P, Nobre GC, Valentini NC. Affordances em ambientes domésticos e desenvolvimento motor de pré-escolares. Rev Pensar Prática. 2012;15(3):652-68. DOI: http://dx.doi.org/10.5216/rpp.v15i3.15412 
14. Silva J, Fronio JS, Lemos RA, Ribeiro LC, Aguiar TS, Silva DT, et al. Pacing opportunities at home and skill of children with potential changes in functional development. J Hum Growth Dev. 2015;25(1):19-26. DOI: http://dx.doi.org/10.7322/jhgd.96763

15. Rodrigues LP, Saraiva L, Gabbard C. Development and structural validation o fan inventory for assessing affordances in the home environment for motor development. Res Quar Exerc Sport. 2005;76(2):140-8. DOI: http://dx.doi.org/10.1080/02701367.2005.10599276

16. Caçola P, Gabbard C, Santos DC, Batistela AC. Development of the and affordances in the home environment for motor development-infant scale. Pediatr Int. 2011;53(6):820-5. DOI: http://dx.doi.org/10.1111/ j.1442-200X.2011.03386.x

17. Valentini NC, Barbosa MLL, Cini GV, Piki RK, Spessato BC, Balbinotti MAA. Teste de desenvolvimento motor grosso: validade e consistência interna para uma população gaúcha. Rev Bras Cineantropom Desempenho Hum. 2008;10(4):399-404. DOI: http://dx.doi.org/10.5007/1980-0037.2008v10n4p399

18. Baltieri L, Santos DCC, Gibim NC, Souza CT, Batistela ACT, Tolocka RE. Desempenho motor de lactentes frequentadores de berçários em creches públicas. Rev Paul Pediatr. 2010; 28(3):283-9. DOI: http://dx.doi. org/10.1590/S0103-05822010000300005

19. Pillatti I, Haas T, Sachetti A, Fontana C, Oliveira SG, Schiavinato JCC. Oportunidades para o Desenvolvimento Motor Infantil em Ambientes Domésticos. Rev Bras Ciênc Saúde. 2011;9(27):22-7. DOI: http:// dx.doi.org/10.13037/rbcs.vol9n27.1335

20. Defilipo EC, Frônio JS, Teixeira MTB, Leite ICG, Bastos RR, Vieira MT, et al. Oportunidades do ambiente domiciliar para o desenvolvimento motor. Rev Saúde Pública. 2012;46(4):633-41. DOI: http://dx.doi. org/10.1590/S0034-89102012005000040

21. Freiras TCB, Gabard C, Caçola P, Montebelo MIL, Santos DCC. Family socioeconomic status and the provision of motor affordances in the home. Braz J Phys Ther. 2013;17(4):319-27. DOI: http://dx.doi. org/10.1590/S1413-35552013005000096

22. Nascimento Junior JRA, Ferreira L, Nickeingvissoci JR, Silva PN, Caruzzo NM, Vieira JLL. Nível socioeconômico e Affordance do ambiente domiciliar: implicações para o desenvolvimento motor infantil. Rev Educ Fís. 2014;25(4):651-62. DOI: http://dx.doi.org/10.4025/reveducfis.v25i4.26529

23. Soares E, Flores, F, Katzer J, Valentini N, Corazza S, Copetti F. Análise das oportunidades de estimulação motora em ambientes domiciliares na região central do Rio Grande do Sul. Rev Bras Educ Fís Esporte. 2015;29(2):279-88. DOI: http://dx.doi.org/10.1590/1807-55092015000200279

24. Mori S, Nakamoto H, Mizuochi H, Ikudome S, Gabbard, C. Influence of affordances in home environmenton motor development of young children in Japan. Child Dev Res. 2013; 2013:5. DOI: http://dx.doi. org/10.1155/2013/898406

25. Conti L, Sperb TM. O brinquedo de pré-escolares: um espaço de resignificação cultural. Psic Teor Pesq. 2001;17(1):59-67. DOI: http://dx.doi.org/10.1590/S0102-37722001000100009

26. Padilha J, Seidel J, Copeti F. Análise do desenvolvimento motor e qualidade do ambiente domiciliar de crianças pré-escolares. Rev Saúde (Santa Maria). 2014;40(1):99-108. DOI: http://dx.doi. org/10.5902/2236583410763

27. Spessato BC, Gabbard C, Valentini N, Rudisill M. Gender differences in Brazilian children's fundamental movement skill performance. Early Child Dev Care. 2013;183(7): 916-23. DOI: http://dx.doi.org/10.1080/ 03004430.2012 .689761

28. Brauner LM, Valentini NC. Análise do desempenho motor de crianças participantes de um programa de atividades físicas. Rev Edu Fís. 2009;20(2):205-16. DOI: http://dx.doi.org/10.4025/reveducfisv20n2p205-216

29. Hardy LL, King L, Farrell L, Macniver R, Howett S. Fundamental Movement skill samong Australian preschool children. J Sci Med Sport. 2009;13(5):503-8. DOI: http://dx.doi.org/10.1016/j.jsams.2009.05.010

30. Machado HS, Campos W, Silva SG. Relação Entre Composição Corporal e a Performance de Padrões Motores Fundamentais em Escolares. Rev Bras Atividade Física e Saúde. 2002;7(1):63-70. DOI: http:// dx.doi.org/10.12820/rbafs.v.7n1p63-70

31. Andrade SA, Santos DN, Bastos AC, Pedromônico MRM, Almeida-Filho N, Barreto ML. Ambiente familiar e desenvolvimento cognitivo infantil: uma abordagem epidemiológica. Rev Saude Publica. 2005;39(4):60611. DOI: http://dx.doi.org/10.1590/S0034-89102005000400014

32. Coutinho M, Souza MS, Brauner L, Valentini NC. A rotina de atividades infantis no ambiente doméstico. Rev Pensar Prática. 2015;18(1):76-90 DOI: http://dx.doi.org/10.5216/rpp.v18i1.30597

This article is distributed under the terms of the Creative Commons Attribution 4.0 International License (http://creativecommons.org/licenses/by/4.0/), which permits unrestricted use, distribution, and reproduction in any medium, provided you give appropriate credit to the original author(s) and the source, provide a link to the Creative Commons license, and indicate if changes were made. The Creative Commons Public Domain Dedication waiver (http://creativecommons.org/publicdomain/zero/1.0/) applies to the data made available in this article, unless otherwise stated. 


\section{Resumo}

Introdução: O ambiente em que a criança está inserida e as oportunidades motoras ofertadas a essa é fundamental para o um bom desenvolvimento motor.

Objetivo: Analisar a relação entre as oportunidades de estimulação motora no ambiente familiar e o desenvolvimento motor de crianças de ambos os sexos.

Método: Foram avaliadas 72 crianças, sendo 33 meninos e 39 meninas com idade de 38 a 42 meses. A avaliação foi realizada por meio dos instrumentos, Affordances in the Home Environment for Motor Development (AHEMD) e do Test of Gross Motor Development-2 (TGMD-2). Utilizou-se os Testes, Qui-quadrado, Exato de Fisher, Teste t para amostras independentes, correlação de Pearson e regressão linear múltipla.

Resultados: De forma geral, os domicílios apresentaram baixas oportunidades de estimulação motora, sendo que para os lares com meninos o escore é maior. As meninas obtiveram melhor desempenho nas habilidades locomotoras, enquanto os meninos apresentaram maiores escores nas habilidades de controle de objetos. Encontrou-se correlação significativa para materiais de motricidade fina e materiais de motricidade grossa para os meninos, e variedade de estimulação, materiais de motricidade fina, materiais de motricidade grossa e estimulação motora para as meninas. Desta forma, no sexo masculino, o desemvolvimento motor é explicado pelas variáveis, disponibilização de materiais de motricidade fina e grossa e para o feminino pela estimulação motora, variedade de estimulação e materiais de motricidade fina e grossa.

Conclusão: Diante dos resultados apresentados pode-se concluir que o ambiente domiciliar está diretamente relacionado com o desenvolvimento motor para as meninas e meninos do contexto analisado.

Palavras-chave: estimulação motora, ambiente domiciliar, desenvolvimento motor. 